\title{
PENGARUH MODAL, TEKNOLOGI DAN KEWIRAUSAHAAN TERHADAP NILAI PRODUKSI DAN PENDAPATAN INDUSTRI PAKAIAN JADI
}

\author{
I Wayan Wira Putra ${ }^{1}$ \\ I Made Jember ${ }^{2}$ \\ ${ }^{1,2}$ Fakultas Ekonomi dan Bisnis Universitas Udayana (Unud), Bali, Indonesia \\ E-mail:wiraputraaaaaa@gmail.com
}

\begin{abstract}
The objectives to be achieved in this study, among others, are to determine the effect of capital, technology, entrepreneurship, and production value on the income of the apparel industry in Karangasem Regency. This research was conducted in Karangasem Regency, with business units totaling 30 business units. The method of determining the sample used is the Total Sampling method, which is a sampling technique in which all members of the population are sampled. Data analysis techniques used are path analysis techniques to determine the direct and indirect effects of capital, technology, and entrepreneurship on the value of production and income. Based on the results of the study, it is known that the capital, entrepreneurship, and production value variables have a positive and significant effect on the income of the apparel industry in Karangasem Regency. Meanwhile, the technology variable does not affect the income of the apparel industry in Karangasem Regency. From the calculation of the sobel test, it is known that the variable value of production mediates the variables of capital and entrepreneurship on the income of the apparel industry in Karangasem Regency.
\end{abstract}

Keywords: capital, technology, entrepreneurship, value of production, income

\begin{abstract}
ABSTRAK
Tujuan yang hendak dicapai dalam penelitian ini, antara lain untuk mengetahui pengaruh modal, teknologi, kewirausahaan, dan nilai produksi terhadap pendapatan industri pakaian jadi di Kabupaten Karangasem. Penelitian ini dilakukan di Kabupaten Karangasem, dengan unit usaha berjumlah 30 unit usaha. Metode penentuan sampel yang digunakan adalah metode Total Sampling, yaitu yaitu teknik pengambilan sampel dimana seluruh anggota populasi dijadikan sampel. Teknik analisis data yang digunakan yaitu teknik analisis jalur untuk mengetahui pengaruh langsung dan tidak langsung modal, teknologi, dan kewirausahaan terhadap nilai produksi dan pendapatan.Berdasarkan hasil penelitian, diketahui bahwa variabel modal, kewirausahaan, dan nilai produksi berpengaruh positif dan signifikan terhadap pendapatan industri pakaian jadi di Kabupaten Karangasem. Sedangkan, variabel teknologi tidak berpengaruh terhadap pendapatan industri pakaian jadi di Kabupaten Karangasem. Dari perhitungan uji sobel, diketahui bahwa variabel nilai produksi memediasi variabel modal dan kewirausahaan terhadap pendapatan industri pakaian jadi di Kabupaten Karangasem.
\end{abstract}

Kata Kunci: modal, teknologi, kewirausahaan, nilai produksi, pendapatan 


\section{PENDAHULUAN}

Pembangunan sebagaimana dikonsepkan oleh para ahli telah menciptakan perubahan dalam kehidupan suatu bangsa. Pembangunan adalah suatu proses perubahan menuju ke arah yang lebih baik dan terus menerus untuk mencapai tujuan yakni mewujudkan masyarakat Indonesia yang berkeadilan, berdaya saing, maju dan sejahtera dalam wadah Negara Kesatuan Republik Indonesia (Sukmanegara, 2011). Keberhasilan pembangunan yang dilaksanakan oleh sebuah negara termasuk Negara Indonesia dapat dilihat dari kondisi kesejahteraan masyarakatnya (Marhaeni dkk., 2014). Dalam proses pembangunan selalu diupayakan pertumbuhan ekonomi adalah setinggi mungkin (Dayuh, 2012). Salah satu tujuan pembangunan adalah mengurangi pengangguran dan dengan sendirinya dapat menambah lapangan kerja bagi masyarakat serta dapat meningkatkan pendapatan masyarakat tersebut (Zulhanafi dkk., 2013)

Indonesia sebagai salah satu negara berkembang yang memiliki sasaran pembangunan untuk mewujudkan masyarakat yang adil dan makmur, mengejar pertumbuhan ekonomi, penanganan ketimpangan pendapatan, serta mengurangi kemiskinan. Dalam mengaplikasikannya, pembangunan di Indonesia pada saat ini menitikberatkan pada pembangunan di bidang ekonomi tanpa mengesampingkan bidang-bidang lainnya, dari berbagai sektor yang ada, keberadaan sektor industri merupakan salah satu sektor yang sedang digencarkan di Indonesia. Industri memegang peranan penting untuk mengurangi ekspansi dan kemiskinan di negara-negara berkembang (Bosselmann, 2006). Dalam UU No. 3 Tahun 2014 tentang Perindustrian, industri adalah bentuk kegiatan ekonomi yang mengolah bahan baku dan/atau memanfaatkan sumber daya industri sehingga menghasilkan 
barang yang mempunyai nilai tambah atau manfaat lebih tinggi, termasuk jasa industri.

Perkembangan industri pada masing - masing negara berada pada tahap yang berbeda - beda namun semua negara memandang industri sebagai bagian penting untuk meningkatkan perekonomian (Shanmugasundaram \& Panchanatham, 2011: 232). Sektor industri diyakini sebagai sektor yang dapat memimpin sektor - sektor lain dalam sebuah perekonomian menuju kemajuan perekonomian suatu negara. Sektor industri memiliki peranan penting karena pengembangan sektor industri yang semakin meningkat, berdampak besar pada pembangunan dan pertumbuhan ekonomi (Kusumastuti, 2015). Pembangunan sektor industri memiliki peran dalam meningkatkan Produk Domestik Bruto (PDB), pendapatan devisa dan penciptaan lapangan perkerjaan (Vargas, 2015). Pembangunan pada sektor industri dengan melakukan pengelompokan suatu perusahaan dapat memberikan dampak pada efisiensi dan pertumbuhan produktivitas (Widodo, 2014). Pembangunan industri adalah kegiatan yang memiliki potensi guna dikembangkan mengingat sumber daya alam lokal dan kreativitas masyarakat pada bidang seni maupun kerajinan cukup memberikan kontribusi pada peningkatan kesejahteraan masyarakat untuk lebih maju dan bermutu (Budiartha dan Trunajaya, 2013).

Berkembangnya sektor industri sekarang ini baik sektor industri kecil ataupun menengah menjadikan sektor industri sebagai sektor yang diminati dan dapat berkembang dengan baik apalagi jika didukung dengan teknologi yang juga terus berkembang setiap waktunya. Sektor indutri yang sedang giat - giatnya 
dekembangkan memiliki tujuan untuk menciptakan lapangan pekerjaan yang dapat menyerap tenaga kerja, kemudian dapat meningkatkan perekonomian (Raheman \& Muhamed, 2007).

Provinsi Bali merupakan salah satu provinsi di Indonesia memiliki berbagai potensi untuk dikembangkan yang telah mengalami pertumbuhan di berbagai sektor ekonomi. Industri manufaktur (pengolahan) mampu menunjukkan kontribusinya sebesar 9,184miliar rupiah pada tahun 2017. Selain itu, pembangunann pada sektor industri juga dapat meningkatkan kualitas produksinya dalam proses produksi (Jena, 2010).

Tabel 1.

Total PDRB, PDRB Industri Pengolahan Dan Persentase PDRB Industri Pengolahan Atas Dasar Harga Konstan 2010 Provinsi Bali Tahun 2013-2017

\begin{tabular}{cccc}
\hline Tahun & $\begin{array}{c}\text { Total PDRB } \\
\text { Provinsi Bali } \\
\text { (Miliar Rupiah) }\end{array}$ & $\begin{array}{c}\text { PDRB Industri } \\
\text { Pengolahan } \\
\text { (Miliar Rupiah) }\end{array}$ & $\begin{array}{c}\text { Persentase } \\
\text { PDRB Industri Pengolahan } \\
(\boldsymbol{\%})\end{array}$ \\
\hline 2013 & 114.102 & 7.565 & 6,63 \\
2014 & 121.789 & 8.273 & 6,76 \\
2015 & 129.130 & 8.809 & 6,82 \\
2016 & 137.286 & 9.105 & 6,63 \\
2017 & 144.965 & 9.184 & 6,34 \\
\hline
\end{tabular}

Sumber: BPS Provinsi Bali, 2018

Dilihat dari Tabel 1, pertumbuhan sektor industri pengolahan tetap konsisten berada di atas 6 persen selama 5 tahun terakhir yaitu pada tahun 2013 hingga tahun 2017. Industri pengolahan di Provinsi Bali pada umumnya tumbuh dan berkembang untuk memenuhi permintaan yang terjadi dari aktivitas kepariwisataan serta untuk memenuhi permintaan akan produk industri, baik yang dipasarkan dalam negeri maupun ekspor.

Salah satu jenis usaha pada sektor industri pengolahan adalah industri pakaian jadi. Industri ini mencakup usaha pembuatan pakaian jadi (konveksi) dari 
tekstil/kain dengan cara memotong dan menjahit sehingga siap dipakai, seperti kemeja, celana, kebaya, baju kaos, seragam sekolah, rok, baik dari kain tenun maupun kain rajut yang dijahit (Ovtchinnikov, 2010).Sektor tekstil dan pakaian jadi sangat penting bagi perekonomian di Indonesia (William et al, 2003). Industri pakaian jadi adalah salah satu sektor yang memiliki perkembangan sangat cepat dan memberikan pengaruh terhadap penyerapan tenaga kerja serta merupakan salah satu sektor penunjang pariwisata di Provinsi Bali (Arsha \& Suardika, 2013). Menurut Setyawan (2017), wirausaha di bidang industri pakaian jadi sangat membantu perekonomian serta dapat membantu meningkatkan perdagangan domestik maupun perdagangan internasional dan dapat meningkatkan devisa negara.

Tabel 2.

Jumlah Usaha, Tenaga Kerja, Nilai Produksi serta Persentase Nilai Produksi pada Industri Pakaian Jadi di Provinsi Bali Menurut Kabupaten/Kota tahun 2017

\begin{tabular}{ccccc}
\hline Kabupaten/Kota & $\begin{array}{c}\text { Jumlah } \\
\text { Usaha } \\
\text { (Unit) }\end{array}$ & $\begin{array}{c}\text { Tenaga } \\
\text { Kerja } \\
\text { (Orang) }\end{array}$ & $\begin{array}{c}\text { Nilai Produksi } \\
(\text { Rp.000) }\end{array}$ & $\begin{array}{c}\text { Persentase } \\
\text { Nilai Produksi } \\
(\mathbf{\%})\end{array}$ \\
\hline Denpasar & 664 & 7.588 & 452.612 .506 & 44,14 \\
Klungkung & 16 & 227 & 3.436 .250 & 0,34 \\
Badung & 183 & 4.775 & 500.785 .091 & 48,84 \\
Buleleng & 27 & 156 & 6.415 .777 & 0,62 \\
Gianyar & 42 & 928 & 15.147 .588 & 1,48 \\
Jembrana & 26 & 69 & 2.223 .700 & 0,22 \\
Karangasem & $\mathbf{3 0}$ & $\mathbf{2 8 6}$ & $\mathbf{2 . 1 8 3 . 9 3 6}$ & $\mathbf{0 , 2 1}$ \\
Tabanan & 45 & 730 & 36.322 .200 & 3,54 \\
Bangli & 32 & 243 & 6.251 .400 & 0,61 \\
Total & $\mathbf{1 0 6 5}$ & $\mathbf{1 5 . 0 0 2}$ & $\mathbf{1 . 0 2 5 . 3 7 8 . 4 4 8}$ & $\mathbf{1 0 0}$ \\
\hline
\end{tabular}

Sumber:Data diolah, 2019

Tabel 2 menunjukkan industri pakaian jadi di tiap-tiap kabupaten/kota di Provinsi Bali pada tahun 2017. Dilihat dari nilai produksi yang dihasilkan tiaptiap kabupaten/kota, Kabupaten Badung memberikan kontribusi tertinggi yaitu 
500.785.091.000 rupiah dengan persentase sebesar 48,84 persen, sedangkan Kabupaten Karangasem memiliki nilai produksi terendah yaitu 2.183.936.000 rupiah dengan persentase 0,21 persen.

Sebagai salah satu kabupaten termiskin di Provinsi Bali, Kabupaten Karangasem berada di urutan kedua setelah Kabupaten Buleleng dengan penduduk miskin sebanyak 37.480 jiwa (BPS Provinsi Bali, 2017). Kabupaten Karangasem memiliki nilai produksi terendah dalam industri pakaian jadi yaitu 2.183.936.000 rupiah dengan persentase 0,21 persen, jumlah unit usaha pakaian jadi di Kabupaten Karangasem, yaitu 30 unit usaha, lebih banyak dibandingkan Kabupaten Jembrana, Buleleng dan Klungkung. Jumlah tenaga kerja pada industri pakaian jadi di Kabupaten Karangasem juga bukan yang terendah dibandingkan kabupaten lain di Provinsi Bali, yaitu 286 orang. Jumlah tersebut lebih banyak jika dibandingkan dengan Kabupaten Jembrana 69 orang, Buleleng 156 orang, Klungkung 227 orang dan Bangli 243 orang. Memiliki jumlah unit usaha dan tenaga kerja lebih banyak dibandingkan kabupaten yang disebutkan tadi, Kabupaten Karangasem hanya mampu memperoleh nilai produksi sebesar 2.183.936.000 rupiah, nilai tersebut menempatkan Kabupaten Karangasem sebagai kabupaten dengan nilai produksi pakaian jadi terendah di Provinsi Bali. Mestinya dengan memiliki jumlah unit usaha dan tenaga kerja yang lumayan besar, Kabupaten Karangasem dapat menghasilkan nilai produksi yang lebih besar pula, sehingga nantinya diharapkan akan mampu memberikan dampak yang maksimal terhadap perekonomian bagi masyarakat sekitar. 
Tabel 3.

Jumlah Usaha, Tenaga Kerja, Nilai Produksi serta Persentase Nilai Produksi pada Industri Pakaian Jadi di Kabupaten Karangasem Menurut Kecamatan Tahun 2017

\begin{tabular}{ccccc}
\hline Kecamatan & $\begin{array}{c}\text { Jumlah } \\
\text { Usaha }\end{array}$ & $\begin{array}{c}\text { Tenaga } \\
\text { Kerja }\end{array}$ & $\begin{array}{c}\text { Nilai } \\
\text { Produksi } \\
\text { (Rp.000) }\end{array}$ & $\begin{array}{c}\text { Persentase } \\
\text { Nilai Produksi } \\
(\%)\end{array}$ \\
\hline Abang & - & - & - & - \\
Bebandem & 4 & 47 & 112.613 & 5,16 \\
Karangasem & 21 & 198 & 1.657 .298 & 75,89 \\
Kubu & - & - & - & - \\
Manggis & - & - & - & - \\
Rendang & 2 & 20 & 122.750 & 5,62 \\
Sidemen & 2 & 19 & 129.275 & 5,91 \\
Selat & 1 & 2 & 162.000 & 7,42 \\
Total & 30 & 286 & 2.183 .936 & 100 \\
\hline
\end{tabular}

Sumber:Dinas Perindustrian dan Perdagangan Provinsi Bali, 2018

Tabel 3 menunjukkan industri pakaian jadi di tiap - tiap kecamatan di Kabupaten Karangasem pada tahun 2017. Dari total delapan kecamatan di Kabupaten Karangasem hanya 6 kecamatan yang berkecimpung di industri pakaian jadi. Dilihat dari nilai produksinya, Kecamatan Karangasem memberikan kontribusi tertinggi dengan 1.657.298.000 rupiah dengan persentase 75,89 persen, sedangkan Kecamatan Bebandem memiliki nilai produksi terendah yaitu 112.613.000 rupiah dengan persentase 5,16 persen.

Menurut Seoki (2010), dalam sebuah industri yang berperan penting adalah modal. Modal adalah seluruh dana yang dikeluarkan dalam proses produksi untuk memperoleh penerimaan penjualan (Ahmad, 2004; 72). Biasanya modal kerja tersebut digunakan untuk biaya pekerja, hak pekerja, untuk memproduksi barang serta biaya dalam keperluan lainnya (Pratama, 2010). Modal adalah faktor yang mempunyai peran yang cukup penting dalam proses produksi, karena modal diperlukan ketika pengusaha hendak mendirikan perusahan baru atau untuk memperluas usahanya, tanpa modal yang cukup maka akan 
berpengaruh terhadap kelancaran usaha, sehingga akan mempengaruhi pendapatan yang diperoleh (Utari \& Martini, 2014).

Selain modal, teknologi juga merupakan faktor yang ikut berperan penting dalam proses produksi. Adanya perubahan teknologi juga berpengaruh terhadap output yang diproduksi oleh industri (Pratiwi dkk., 2014). Industri yang efisien hanya dapat dihasilkan melalui penerapan teknologi tepat guna, dengan begitu proses produksi akan lebih mudah dan cepat untuk dilakukan, sehingga jumlah output yang dihasilkan akan meningkat. Dewasa ini, beberapa perusahaan industri sangat terbantu oleh hadirnya teknologi tepat guna, industri-industri pakaian jadi sudah mulai menggunakan teknologi modern dibandingkan dengan teknologi tradisional, contohnya mesih sablon digital. Penggunaan teknologi modern akan menghasilkan barang yang optimal dan hasil yang memuaskan (Nugraha, 2013).

Seiring dengan percepatan perkembangan fashion dunia yang tidak hanya mengandalkan musim tetapi tren mode, menyebabkan pesanan untuk pakaian jadi pun cepat berubah. Dalam meningkatkan keberhasilan usaha dan produktivitas pada industri pakaian jadi, mental kewirausahaan (entrepreneurship) menjadi hal yang penting bagi pengusaha pada industri pakaian jadi. Menurut Suryana (2006:1) kewirausahaan (entrepreneurship) adalah kemampuan kreatif dan inovatif yang dijadikan dasar, kiat, dan sumber daya untuk mencari peluang menuju sukses. Dengan memiliki mental kewirausahaan, maka industri pakaian jadi dapat menghasilkan produk - produk baru yang inovatif dan kreatif agar 
dapat bersaing tidak hanya di pasar domestik teteapi juga di pasar global (Ningsih dan Indrajaya, 2015).

Berkembangnya industri pakaian jadi dapat dijadikan akses untuk mengurangi pengangguran dan menjadi tumpuan dalam meningkatkan sumber pendapatan masyarakat. Seiring berkembangnya industri pakaian jadi ini mendorong meningkatnya pendapatan keluarga sehingga dapat meningkatkan kesejahteraan (Putri dan Jember, 2016). Menurut Carbonell (2005) semakin tingginya tingkat pendapatan seseorang, maka tingkat kebahagiaan yang dirasakan oleh seseorang akan semakin besar dibandingkan dengan seseorang yang pendapatannya lebih rendah. Pendapatan adalah balas jasa yang diterima oleh faktor - faktor produksi dalam jangka waktu tertentu. Balas jasa dalam jangka waktu tersebut berupa sewa, gaji/upah, bunga atau laba (Sukirno: 37). Setiap pelaku usaha yang satu dengan lainnya memiliki tingkat pendapatan yang berbeda - beda. Dari pendapatan tersebut dapat digunakan sebagai alat untuk memenuhi kebutuhan (Kurniawan, 2016). Menurut Olaitan (2006) Peningkatan pendapatan mempunyai pengaruh besar untuk kelangsungan perusahaan, karena pendapatan digunakan dalam kegiatan usaha.

Menurut Vargas (2015), industri adalah konglomerasi perusahaan yang bergerak dalam produksi barang dan jasa yang memiliki beberapa kesamaan satu sama lain. Konsep industri menjelaskan mengenai ruang lingkup industri meliputi semua kegiatan produksi yang bertujuan meningkatkan mutu barang dan jasa. Industri adalah suatu unit usaha yang melakukan kegiatan ekonomi yang bertujuan untuk menghasilkan barang atau jasa, terletak pada suatu bangunanatau 
lokasi tertentu yang mempunyai administrasi sendiri mengenai produksi struktur biaya serta ada seorang atau lebih yang bertanggung jawab atas usaha tersebut.

Industri manufaktur merupakan kegiatan ekonomi yang luas maka jumlah dan macam industri berbeda untuk tiap negara atau daerah. Pada umumnya, makin maju tingkat perkembangan perindustrian di suatu negara atau daerah, maka makin banyak jumlah dan macam industri, dan makin kompleks pula sifat kegiatan dan usaha tersebut. Cara penggolongan atau pengklasifikasian industri pun berbeda - beda. Tetapi pada dasarnya, pengklafikasian industri didasarkan pada kriteria yaitu berdasarkan bahan baku, tenaga kerja, pangsa pasar, modal, atau jenis teknologi yang digunakan.

Menurut Seoki (2010), dalam sebuah industri yang berperan penting adalah modal. Modal adalah seluruh dana yang dikeluarkan dalam proses produksi untuk memperoleh penerimaan penjualan (Ahmad, 2004; 72). Penelitian yang dilakukan oleh Hafidh (2009) dan Huazhang (2014) membuktikan bahwa modal berpengaruh positif terhadap hasil produksi. Biasanya modal kerja tersebut digunakan untuk biaya pekerja, hak pekerja, untuk memproduksi barang serta biaya dalam keperluan lainnya (Pratama, 2010).

Menurut Mankiw (2014:413), pendapatan perorangan merupakan pendapatan yang diterima oleh rumah tangga dan yang bukan perusahaan. Pendapatan perorangan turut menghitung pendapatan bunga yang diterima oleh rumah tangga yang berasal dari kepemilikan mereka atas utang negara. Pendapatan perorangan juga mengurangi pajak pendapatan perusahaan dan kontribusi pada tunjangan nasional. 
Dalam teori mikro, pendapatan dapat dihitung dengan cara mengalikan antara harga dengan jumlah kualitas yang terjual. Sedangkan pendapatan rata-rata yaitu jumlah pendapatan total yang dibagi dengan jumlah penduduk. Keuntungan suatu perusahaan dapat diperoleh dari hasil pengurangan pendapatan total dengan biaya total yang dikeluarkan oleh perusahaan tersebut (Mankiw, 2014:291).

Menurut Eric Schatzberg (2006), teknologi adalah metode ilmiah untuk mencapai tujuan praktis, ilmu pengetahuan terapan atau dapat pula diterjemahkan sebagai keseluruhan sarana untuk menyediakan barang - barang yang diperlukan bagi kelangsungan dan kenyamanan hidup manusia. Dalam penelitian yang dilakukan oleh Prianata dan Suardhika (2014), menyebutkan teknologi secara parsial berpengaruh positif terhadap produksi industri furniture di Kota Denpasar. Dengan teknologi yang semakin modern maka dalam proses produksi akan memberikan efisiensi dalam masalah waktu, tenaga, dan biaya.

Menurut Glancey dalam Sony Heru Priyanto (2009:73), wirausaha yang memiliki kemampuan mengambil keputusan yang superior akan dapat meningkatkan performansi usaha seperti peningkatan profit dan petumbuhan usaha. Kewirausahaan kebanyakan ditinjau dari sudut keberhasilan para pengusaha, perubahan kerangka kerja ekonomi dan kapitalisme. Penelitian yang dilakukan oleh Hinsatopa Simatupang (2009) menyimpulkan bahwa kewirausahaan berpengaruh terhadap produktivitas usaha industri kelapa sawit Provinsi Riau.

Produksi adalah proses menghasilkan atau memperoleh barang atau jasa dengan menggunakan atau menginput faktor produksi untuk menghasilkan output 
(barang dan jasa) yang berguna untuk memenuhi berbagai kebutuhan masyarakat (Prastyo dan Kartika, 2017). Teori menyebutkan bahwa kepuasan produsen diperoleh dengan memaksimumkan keuntungan produksi (maksimation of profit). Menurut Ningsih dan Bagus (2015), produksi merupakan kegiatan yang dilakukan oleh produsen berupa mengkombinasikan sumber daya untuk menghasilkan output. Kemudian Budiartha dan Trunajaya (2013) mendefinisikan produksi adalah suatu proses kegiatan pengolahan bahan baku menjadi barang yang bernilai guna, produksi merupakan proses transformasi (perubahan) dari input menjadi output. Sumber daya atau input dikelompokkan menjadi sumber daya manusia (termasuk tenaga kerja dan kemampuan manajerial/entrepreneurship), modal (capital), tanah atau sumber daya alam (Sugiyanto, 2002: 88).

Berdasarkan hasil penelitian Adhiatma (2014), menyatakan bahwa modal secara parsial berpengaruh secara signifikan terhadap pendapatan pedagang kayu glondong di Kelurahan Karangkebagusan Jepara. Hal sejalan juga dipaparkan oleh penelitian Utari dan Martini (2014) yang berjudul Pengaruh Modal, Tingkat Pendidikan, Dan Teknologi Terhadap Pendapatan Usaha Mikro Kecil Dan Menengah (UMKM) Di Kawasan Imam Bonjol Denpasasr Barat. Penelitian tersebut menyatakan bahwa modal secara parsial berpengaruh positif dan signifikan terhadap pendapatan UMKM di kawasan Imam Bonjol, Denpasar Barat. Artinya semakin besar modal yang dikonsumsi maka semakin besar pendapatan yang diterima.

Dalam jurnal oleh Tri Utami dan Martini Dewi (2014), menyebutkan bahwa teknologi secara parsial berpengaruh positif dan signifikan terhadap 
pendapatan. Hal sejalan juga dinyatakan oleh Rahman \& Awalia (2016), pada jurnal yang berjudul Faktor Yang Mempengaruhi Pendapatan Nelayan Di Desa Aeng Batu - Batu Kecamatan Galesong Utara Kabupaten Takalar, yang menyatakan bahwa teknologi secara parsial berpengaruh signifikan dan berhubungan positif terhadap pendapatan nelayan. Hal ini mengidentifikasikan bahwa semakin modern teknologi yang diadopsi maka pendapatan yang akan diterima semakin meningkat juga.

Dalam penelitian yang berjudul Pengaruh Perilaku Kewirausahaan Terhadap Pendapatan Pengusaha Rajut Di Sentra Industri Rajut Binong Jati Kota Bandung oleh Pamella (2014), menyebutkan bahwa perilaku kewirausahaan berpengaruh positif terhadap pendapatan pengusaha rajut Binong Jati. Penelitian yang dilakukan oleh Furqon (2017) juga menyatakan bahwa kewirausahaan berpengaruh positif dan signifikan terhadap pendapatan. Artinya, semakin tinggi atau semakin baik sikap kewirausahaan yang dimilikii oleh pengusaha maka semakin besar pendapatan yang diperoleh. Produksi adalah proses menghasilkan atau memperoleh barang atau jasa dengan menggunakan atau menginput faktor produksi untuk menghasilkan output (barang dan jasa) yang berguna untuk memenuhi berbagai kebutuhan masyarakat (Prastyo dan Kartika, 2017). Bertambahnya produksi yang dihasilkan, maka secara otomatis akan meningkatkan penjualan perusahaan dan dengan harga yang lebih dari pengeluaran perusahaan sehingga akan mempengaruhi meningkatnya pendapatan bagi perusahaan (Arfiani, 2013). 


\section{METODE PENELITIAN}

Penelitian ini dilakukan di Kabupaten Karangasem, pemilihan lokasi ini didasari karena nilai produksi industri pakaian jadi di Kabupaten Karangasem menempati posisi terendah diantara kabupaten lainnya di Provinsi Bali, yaitu sebesar 2.183.936.000 rupiah dengan persentase 0,21 persen, padahal jumlah unit usaha pakaian jadi di Kabupaten Karangasem lebih banyak dibandingkan Kabupaten Jembrana, yaitu 30 unit usaha, lebih banyak dibandingkan Kabupaten Jembrana, Buleleng dan Klungkung. Jumlah tenaga kerja pada industri pakaian jadi di Kabupaten Karangasem juga bukan yang terendah dibandingkan kabupaten lain di Provinsi Bali, yaitu 286 orang. Jumlah tersebut lebih banyak jika dibandingkan dengan Kabupaten Jembrana 69 orang, Buleleng 149 orang, Klungkung 236 orang dan Bangli 238 orang.

Populasi yang digunakan peneliti dalam penelitian ini adalah seluruh usaha industri pakaian jadi di Kabupaten Karangasem tahun 2017 yaitu sebanyak 30 unit usaha.Penelitian ini menggunakan teknik Total Sampling, yaitu teknik pengambilan sampel dimana seluruh anggota populasi dijadikan sampel semua. Teknik ini digunakan pada penelitian dengan populasi di bawah 100. Jadi, dalam penelitian ini menggunakan seluruh populasi sebagai sampel yaitu 30 unit usaha industri pakaian jadi di Kabupaten Karangasem.Teknik analisis data yang digunakan untuk memecahkan permasalahan dalam penelitiaan ini adalah metode analisis jalur (Path Analysis). 


\section{HASIL DAN PEMBAHASAN}

Uji validitas bertujuan untuk memeriksa apakah kuesioner sebagai instrumen penelitian sudah tepat untuk mengukur apa yang seharusnya diukur. Suatu instrumen dikatakan valid apabila memiliki koefisien korelasi antara butir dengan skor total dalam instrumen tersebut lebih besar dari 0,30 dengan tingkat kesalahan Alpha 0,05. Tabel 1berikut menyajikan hasil uji validitas instrumen penelitian.

Tabel 4.

Rekapitulasi Hasil Uji Validitas Instrumen Penelitian

\begin{tabular}{ccccc}
\hline Variabel & Indikator & $\begin{array}{c}\text { Koefisien } \\
\text { Korelasi }\end{array}$ & $\begin{array}{c}\text { Sig. (2- } \\
\text { tailed) }\end{array}$ & Keterangan \\
\hline \multirow{3}{*}{ Kewirausahaan $(\mathrm{X} 3)$} & $\mathrm{X}_{3.1}$ & 0,666 & 0,000 & Valid \\
& $\mathrm{X}_{3.2}$ & 0,653 & 0,000 & Valid \\
& $\mathrm{X}_{3.3}$ & 0,663 & 0,000 & Valid \\
& $\mathrm{X}_{3.4}$ & 0,820 & 0,000 & Valid \\
\hline
\end{tabular}

Sumber: Data diolah, 2019

Hasil uji validitas pada Tabel 4 menunjukkan bahwa seluruh instrumen penelitian yang digunakan untuk mengukur variabelorientasi pasar, inovasi produk dan kinerja pemasaran memiliki nilai koefisien korelasi dengan skor total seluruh item pernyataan lebih besar dari 0,30 dengan signifikansi kurang dari 0,05. Hal ini menunjukkan bahwa butir-butir pernyataan dalam instrument penelitian tersebut valid dan layak digunakan sebagai instrument penelitian.

Uji Reliabilitas terhadap instrumen penelitian ini menggunakan nilai Alpha Cronbach, yakni untuk mengetahui unidimensionalitas butir-butir pernyataan terhadap variabel laten yang diteliti (Orientasi Pasar, Inovasi Produk dan Kinerja pemasaran). Nilai Alpha Cronbach dinyatakan reliabel jika nilainya lebih besar atau sama dengan 0,60 . Rekapitulasi hasil uji reliabilitas instrumen penelitian dapat dilihat pada Tabel 5 . 
Tabel 5.

Rekapitulasi Hasil Uji Reliabilitas Instrumen Penelitian

\begin{tabular}{cccc}
\hline No. & Variabel & Cronbach's Alpha & Keterangan \\
\hline $\mathbf{1}$ & Kewirausahaan $(\mathrm{X} 3)$ & 0,778 & Reliabel \\
\hline Sumber: & Data diolah, 2019 & &
\end{tabular}

Hasil uji reliabilitas yang disajikan dalam Tabel 5 menunjukkan bahwa seluruh instrumen penelitian memiliki koefisien Cronbach's Alpha lebih dari 0,60. Jadi dapat dinyatakan bahwa seluruh variabel telah memenuhi syarat reliabilitas atau kehandalan sehingga dapat digunakan untuk melakukan penelitian.

Tabel 6.

Jumlah Responden Penelitian Berdasarkan Nilai Produksi

\begin{tabular}{ccc}
\hline Nilai Produksi & Jumlah & Persentase (\%) \\
\hline $3.700 .000-19.765 .000$ & 20 & 66,67 \\
$19.770 .000-35.825 .000$ & 6 & 20 \\
$35.830 .000-51.895 .000$ & 2 & 6,67 \\
$51.900 .000-67.965 .000$ & 1 & 3,33 \\
$67.970 .000-84.000 .000$ & 1 & 3,33 \\
Total & 30 & 100 \\
\end{tabular}

Sumber: Data diolah, 2019

Nilai produksi dalam penelitian ini adalah jumlah outputyang dihasilkan dikalikan harga jual pakaian jadi baik yang sudah terjual maupun belum terjual dengan menggunakan nilai selama satu bulan dalam jutaan rupiah. Berdasarkan Tabel 3 responden dengan nilai produksi antara 3.700.000 - 19.765.000 rupiah sebanyak 20 responden atau 66,67 persen, sedangkan responden dengan nilai produksi antara $67.970 .000-84.000 .000$ rupiah terdapat 1 responden atau 3,33 persen. 
Tabel 7.

Jumlah Responden Penelitian Berdasarkan Pendapatan

\begin{tabular}{ccc}
\hline Pendapatan & Jumlah & Persentase $(\%)$ \\
\hline $1.295 .000-5.236 .000$ & 19 & 63,33 \\
$5.237 .000-9.178 .000$ & 8 & 26,67 \\
$9.179 .000-13.120 .000$ & 1 & 3,33 \\
$13.121 .000-17.062 .000$ & 0 & 0 \\
$17.063 .000-21.000 .000$ & 2 & 6,67 \\
Total & 30 & 100 \\
\hline
\end{tabular}

Sumber: Data diolah, 2019

Pendapatan dalam penelitian ini adalah hasil yang diperoleh industri pakaian jadi di Kabupaten Karangasem yang dinyatakan dalam jutaan rupiah per bulan. Pendapatan diukur dengan mengurangi total dari nilai produksi dengan biaya operasional per bulan. Berdasarkan Tabel 7 responden dengan pendapatan antara 1.295.000 - 5.236.000 rupiah sebanyak 19 orang atau 63,33 persen dan responden dengan pendapatan antara 17.063.000 - 21.000.000 rupiah sebanyak 2 responden atau 6,67 persen.

Perhitungan koefisien path dilakukan dengan menggunakan software SPSS 18.0 for Windows, dan diperoleh hasil yang ditunjukan pada Tabel 8 .

Tabel 8.

Hasil Uji Path Analysis (Struktur 1)

\begin{tabular}{llrrrrr}
\hline Model & & \multicolumn{2}{c}{$\begin{array}{c}\text { Unstandardized } \\
\text { Coefficients }\end{array}$} & $\begin{array}{c}\text { Standardized } \\
\text { Coefficients } \\
\text { Beta }\end{array}$ & \multicolumn{1}{c}{ t } & \multicolumn{1}{c}{ Sig. } \\
\hline 1 & B & Std. Error & .020 & & -.504 & .618 \\
& (Constant) & -.010 & .022 & .980 & 45.225 & .000 \\
& Modal & .985 & .021 & .003 & .154 & .879 \\
& Teknologi & .003 & .021 & .050 & 2.302 & .030 \\
\hline
\end{tabular}

Sumber: Data diolah, 2018

Berdasarkan hasil analisis jalur substruktur 1 seperti yang disajikan pada

Tabel 8, maka dapat dibuat persamaan struktural Y1.

$$
\mathrm{Y} 1=0,980 \mathrm{X}_{1}+0,003 \mathrm{X}_{2}+0,050 \mathrm{X}_{3}+0,114 \mathrm{e}_{1}
$$


Nilai koefisien regresi variabel modal dan kewirausahaan memiliki nilai signifikansi uji t kurang dari 0,10. Hal ini menunjukkan bahwa variabel modal $\left(\mathrm{X}_{1}\right)$ dan kewirausahaan $\left(\mathrm{X}_{3}\right)$, memiliki pengaruh yang signifikan terhadap variabel nilai produksi $\left(\mathrm{Y}_{1}\right)$. Sedangkan, nilai koefisien regresi variabel teknologi memiliki nilai signifikansi uji t lebih dari 0,10 . Hal ini menunjukkan bahwa variabel teknologi $\left(\mathrm{X}_{2}\right)$ tidak memiliki pengaruh yang signifikan terhadap variabel nilai produksi $\left(\mathrm{Y}_{1}\right)$.

Tabel 9.

Hasil Uji Path Analysis (Struktur 2)

\begin{tabular}{llrrrrr}
\hline Model & \multicolumn{7}{c}{$\begin{array}{c}\text { Unstandardized } \\
\text { Coefficients }\end{array}$} & $\begin{array}{c}\text { Standardized } \\
\text { Coefficients } \\
\text { Beta }\end{array}$ & \multicolumn{1}{c}{ t } & \multicolumn{1}{c}{ Sig. } \\
\hline 1 & B & Std. Error & .010 & & .578 & .568 \\
& Modal & .006 & .095 & .483 & 5.057 & .000 \\
& Teknologi & .483 & .010 & .004 & .364 & .719 \\
& Kewirausahaan & .004 & .010 & .049 & 4.190 & .000 \\
& Nilai Produksi & .051 & .012 & .531 & 5.472 & .000 \\
\hline
\end{tabular}

Sumber:Data diolah, 2019

Berdasarkan hasil analisis jalur substruktur 2 seperti yang disajikan pada Tabel 9, maka dapat dibuat persamaan struktural Y2.

$$
\mathrm{Y} 2=0,483 \mathrm{X}_{1}+0,004 \mathrm{X}_{2}+0,049 \mathrm{X}_{3}+0,531 \mathrm{Y}_{1}+0,055 \mathrm{e}_{2}
$$

Nilai koefisien regresi variabel modal, kewirausahaan, dan nilai produksi memiliki nilai signifikansi uji t kurang dari 0,10. Hal ini menunjukkan bahwa variabel modal $\left(\mathrm{X}_{1}\right)$, kewirausahaan $\left(\mathrm{X}_{3}\right)$, dan nilai produksi $\left(\mathrm{Y}_{1}\right)$ memiliki pengaruh yang signifikan terhadap variabel pendapatan $\left(\mathrm{Y}_{2}\right)$. Sedangkan, nilai koefisien regresi variabel teknologi memiliki nilai signifikansi uji t lebih dari 0,10. Hal ini menunjukkan bahwa variabel teknologi $\left(\mathrm{X}_{2}\right)$ tidak memiliki pengaruh yang signifikan terhadap variabel pendapatan $\left(\mathrm{Y}_{2}\right)$. 
Koefisien determinasi pada intinya mengukur seberapa jauh kemampuan model dalam menerangkan variasi variabel dependen (Ghozali, 2016). Dalam perhitungan statistik ini, nilai $\mathrm{R}^{2}$ yang digunakan adalah adjusted $\mathrm{R}^{2}$ karena ini merupakan salah satu indikator untuk mengetahui pengaruh penambahan satu variabel independen kedalam satu persamaan regresi. Hasil uji koefisien determinasi dalam penelitian ini dapat dilihat secara lengkap pada Lampiran 6 yang dirangkum dalam Tabel 10.

Tabel 10.

Hasil Koefisien Determinasi

\begin{tabular}{clcc}
\hline Struktur & \multicolumn{1}{c}{ Persamaan } & R Square & $\begin{array}{c}\text { Adjusted } \boldsymbol{R} \\
\text { Square }\end{array}$ \\
\hline 1 & $\mathrm{Y} 1=0,980 \mathrm{X}_{1}+0,003 \mathrm{X}_{2}+0,050 \mathrm{X}_{3}+0,114 \mathrm{e}_{1}$ & 0,989 & 0,987 \\
2 & $\mathrm{Y} 2=0,483 \mathrm{X}_{1}+0,004 \mathrm{X}_{2}+0,049 \mathrm{X}_{3}+0,531 \mathrm{Y}_{1}+0,055$ & 0,997 & 0,997 \\
\hline
\end{tabular}

Sumber:Data diolah, 2019

Tabel 10 menunjukkan pada persamaan struktur 1 (analisis jalur 1) besarnya pengaruh variabel bebas terhadap variabel terikat yang ditunjukkan oleh nilai determinasi (Adjusted $R$ Square) sebesar 0,987 mempunyai arti bahwa sebesar 98,7\% variasi nilai produksi dipengaruhi oleh variasi modal $\left(\mathrm{X}_{1}\right)$, teknologi $\left(\mathrm{X}_{2}\right)$, dan kewirausahaan $\left(\mathrm{X}_{3}\right)$, sedangkan sisanya sebesar 1,3\% dijelaskan oleh faktor lain yang tidak dimasukkan ke dalam model.Sedangkan pada persamaan struktur 2 (analisis jalur 2) besarnya pengaruh variabel bebas terhadap variabel terikat yang ditunjukkan oleh nilai determinasi (Adjusted $R$ Square) sebesar 0,997 mempunyai arti bahwa sebesar 99,7\% variasi pendapatan dipengaruhi oleh variasi modal $\left(\mathrm{X}_{1}\right)$, teknologi $\left(\mathrm{X}_{2}\right)$, kewirausahaan $\left(\mathrm{X}_{3}\right)$, dan nilai produksi(Y1), sedangkan sisanya sebesar $0,3 \%$ dijelaskan oleh faktor lain yang tidak dimasukkan ke dalam model. 
Berdasarkan model substruktur 1 dan substruktur 2, maka dapat disusun model diagram jalur akhir. Sebelum menyusun model diagram jalur akhir, terlebih dahulu dihitung nilai standar eror sebagai berikut :

$$
\begin{aligned}
& \mathrm{e}_{\mathrm{i}}=\sqrt{1-\mathrm{R}_{\mathrm{i}}{ }^{2}} \\
& \mathrm{e}_{1}=\sqrt{1-{R_{1}}^{2}}=\sqrt{1-0,987}=0,114 \\
& \mathrm{e}_{2}=\sqrt{1-{R_{2}}^{2}}=\sqrt{1-0,997}=0,055
\end{aligned}
$$

Berdasarkan perhitungan pengaruh error (ei), didapatkan hasil pengaruh error $\left(\mathrm{e}_{1}\right)$ sebesar 0,114 dan pengaruh error $\left(\mathrm{e}_{2}\right)$ sebesar 0,055 . Hasil koefisien determinasi total adalah sebagai berikut :

$$
\begin{aligned}
\mathrm{R}^{2} \mathrm{~m} & =1-\left(\mathrm{e}_{1}\right)^{2}\left(\mathrm{e}_{2}\right)^{2} \\
& =1-(0,114)^{2}(0,055)^{2} \\
& =1-(0,013)(0,003) \\
& =1-0,000039=0,999961
\end{aligned}
$$

Nilai determinasi total sebesar 0,999 mempunyai arti bahwa sebesar 99,9\% variasi pendapatan dipengaruhi oleh variasi modal, teknologi, kewirausahaan, dan nilai produksi, sedangkan sisanya sebesar $0,1 \%$ dijelaskan oleh faktor lain yang tidak dimasukkan ke dalam model.

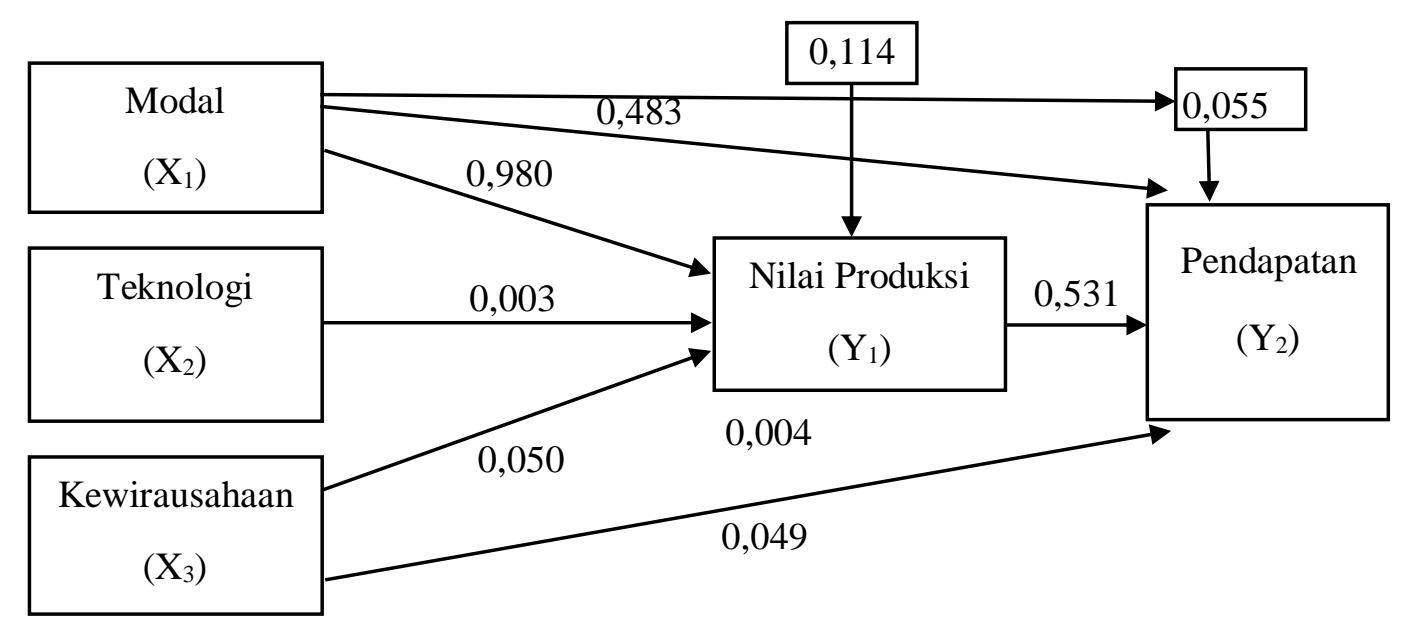

Sumber: Data diolah, 2019 


\section{Gambar 1. Model Diagram Jalur Akhir}

Berdasarkan diagram jalur pada Gambar 1, maka dapat dihitung besarnya pengaruh langsung dan pengaruh tidak langsung serta pengaruh total antar variabel. Perhitungan pengaruh antar variabel dirangkum dalam Tabel 11.

Tabel 11.

Pengaruh Langsung dan Pengaruh Tidak Langsung serta Pengaruh Total Variabel Penelitian

\begin{tabular}{cccc}
\hline $\begin{array}{c}\text { Pengaruh } \\
\text { Variabel }\end{array}$ & $\begin{array}{c}\text { Pengaruh } \\
\text { Langsung }\end{array}$ & Pengaruh Tidak Langsung & Pengaruh Total \\
\hline $\mathrm{X}_{1} \rightarrow \mathrm{Y}_{1}$ & 0,980 & - & 0,980 \\
$\mathrm{X}_{2} \rightarrow \mathrm{Y}_{1}$ & 0,003 & - & 0,003 \\
$\mathrm{X}_{3} \rightarrow \mathrm{Y}_{1}$ & 0,050 & - & 0,050 \\
$\mathrm{Y}_{1} \rightarrow \mathrm{Y}_{2}$ & 0,531 & - & 0,531 \\
$\mathrm{X}_{1} \rightarrow \mathrm{Y}_{2}$ & 0,483 & $(0,980 \times 0,531)=0,520$ & 1,003 \\
$\mathrm{X}_{2} \rightarrow \mathrm{Y}_{2}$ & 0,004 & $(0,003 \times 0,531)=0,002$ & 0,006 \\
$\mathrm{X}_{3} \rightarrow \mathrm{Y}_{2}$ & 0,049 & $(0,050 \times 0,531)=0,027$ & 0,076 \\
\hline Sumber: Data diolah, 2019 & &
\end{tabular}

Uji kelayakan model (Uji F) pada dasarnya menunjukkan apakah variabel independen yang dimasukkan dalam model mempunyai pengaruh secara bersamasama terhadap variabel terikat (Ghozali, 2016). Apabila nilai signifikansi Fhitung atau $\mathrm{P}$ value $\leq 0,10$ maka pengaruh variabel-variabel independen adalah signifikan berpengaruh pada variabel dependen. Hasil uji simultan (uji F) dalam penelitian ini dapat dilihat secara lengkap yang dirangkum dalam Tabel 12.

Tabel 12.

Hasil Uji F

\begin{tabular}{clcc}
\hline Struktur & \multicolumn{1}{c}{ Persamaan } & F statistik & $\begin{array}{c}\text { Signifikansi } \\
\text { Uji F }\end{array}$ \\
\hline 1 & $\mathrm{Y} 1=0,980 \mathrm{X}_{1}+0,003 \mathrm{X}_{2}+0,050 \mathrm{X}_{3}+0,114 \mathrm{e}_{1}$ & 759,476 & 0,000 \\
2 & $\mathrm{Y} 2=0,483 \mathrm{X}_{1}+0,004 \mathrm{X}_{2}+0,049 \mathrm{X}_{3}+0,531 \mathrm{Y}_{1}+$ & 2350,505 & 0,000 \\
& $0,055 \mathrm{e}_{2}$ & & \\
\hline
\end{tabular}

Sumber:Data diolah, 2019 
Hasil uji F (Ftest) yang terdapat pada Lampiran 6 dan yang dirangkum dalam Tabel 12 menunjukkan bahwa nilai $\mathrm{F}$ hitung pada persamaan struktur 1 (analisis jalur 1) sebesar 759,476dengan nilai signifikansi $\mathrm{P}$ value 0,000 yang lebih kecil dari $\alpha=0,10$, ini berarti model yang digunakan pada penelitian ini adalah layak. Hasil ini memberikan makna bahwa seluruh variabel independen yaitu modal $\left(\mathrm{X}_{1}\right)$, teknologi $\left(\mathrm{X}_{2}\right)$, dan kewirausahaan $\left(\mathrm{X}_{3}\right)$ berpengaruh secara simultan terhadap nilai produksi. Hal ini berarti model dapat digunakan untuk analisa lebih lanjut atau dengan kata lain model dapat digunakan untuk memproyeksikan karena hasil goodness of fitnya baik dengan nilai signifikansi $\mathrm{P}$ value 0,000 .

Hasil uji F (Ftest) yang terdapat pada Lampiran 6 dan yang dirangkum dalam Tabel 12 menunjukkan bahwa nilai $\mathrm{F}$ hitung pada persamaan struktur 2 (analisis jalur 2) sebesar 2350,505dengan nilai signifikansi $\mathrm{P}$ value 0,000 yang lebih kecil dari $\alpha=0,10$, ini berarti model yang digunakan pada penelitian ini adalah layak. Hasil ini memberikan makna bahwa seluruh variabel independen yaitu modal $\left(\mathrm{X}_{1}\right)$, teknologi $\left(\mathrm{X}_{2}\right)$, kewirausahaan $\left(\mathrm{X}_{3}\right)$, dan nilai produksi $\left(\mathrm{Y}_{1}\right)$ berpengaruh secara simultan terhadap pendapatan. Hal ini berarti model dapat digunakan untuk analisa lebih lanjut atau dengan kata lain model dapat digunakan untuk memproyeksikan karena hasil goodness of fitnya baik dengan nilai signifikansi $\mathrm{P}$ value 0,000 .

Berdasarkan hasil analisis pengaruh modal terhadap nilai produksidiperoleh nilai Signifikasi sebesar 0,000 dengan nilai koefisien regresi 0,985. Nilai Signifikansi $0,000<0,10$ mengindikasikan bahwa $\mathrm{H}_{1}$ diterima dan $\mathrm{H}_{0}$ 
ditolak. Hasil ini mempunyai arti bahwa modalberpengaruh positif dan signifikan terhadap nilai produksi industri pakaian jadi di Kabupaten Karangasem.Penelitian yang dilakukan oleh Hafidh (2009) dan Huazhang (2014) membuktikan bahwa modal berpengaruh positif terhadap hasil produksi, maka dapat disimpulkan jika modal meningkat maka nilai produksi akan ikut meningkat.

Berdasarkan hasil analisis pengaruh teknologi terhadap nilai produksi diperoleh nilai signifikansi sebesar 0,879 dengan nilai koefisien regresi 0,003 . Nilai Signifikansi 0,879> 0,10 mengindikasikan bahwa $\mathrm{H}_{1}$ ditolak dan $\mathrm{H}_{0}$ diterima. Hasil ini mempunyai arti industri pakaian jadidengan teknologi modernmemiliki nilai produksi tidak lebih tinggi daripada industri pakaian jadi dengan teknologitradisional di Kabupaten Karangasem. Deviyanova dan Prihadi Utomo (2017), mengemukakan bahwa teknologi tidak memberikan pengaruh yang signifikan terhadap nilai produksi. Sri Yuniartini (2013) menyatakan bahwa teknologi tidak berpengaruh terhadap nilai produksi.

Berdasarkan hasil analisis pengaruh kewirausahaan terhadap nilai produksi diperoleh nilai signifikansi sebesar 0,030 dengan nilai koefisien regresi 0,052 . Nilai Signifikansi $0,030<0,10$ mengindikasikan bahwa $\mathrm{H}_{1}$ diterima dan $\mathrm{H}_{0}$ ditolak. Hasil ini mempunyai arti bahwa kewirausahaan berpengaruh positif dan signifikan terhadap nilai produksi industri pakaian jadi di Kabupaten Karangasem.Penelitian yang dilakukan oleh Hinsatopa Simatupang (2009) menyimpulkan bahwa kewirausahaan berpengaruh terhadap produktivitas usaha industri kelapa sawit Provinsi Riau. Jadi wirausaha yang memiliki kemampuan 
mengambil keputusan yang superior akan dapat meningkatkan performansi usaha seperti peningkatan nilai produksi dan petumbuhan usaha.

Berdasarkan hasil analisis pengaruh modal terhadap pendapatandiperoleh nilai signifikasi sebesar 0,000 dengan nilai koefisien regresi 0,483 . Nilai Signifikansi $0,000<0,10$ mengindikasikan bahwa $\mathrm{H}_{1}$ diterima dan $\mathrm{H}_{0}$ ditolak. Hasil ini mempunyai arti bahwa modal berpengaruh positif dan signifikan terhadap pendapatan industri pakaian jadi di Kabupaten Karangasem. Hasil penelitian Adhiatma (2014), menyatakan bahwa modal secara parsial berpengaruh secara signifikan terhadap pendapatan pedagang kayu glondong di Kelurahan Karangkebagusan Jepara, maka dapat disimpulkan jika semakin besar modal maka pendapatan akan semakin meningkat.

Berdasarkan hasil analisis pengaruh teknologi terhadap pendapatandiperoleh nilai signifikansi sebesar 0,719 dengan nilai koefisien regresi 0,004. Nilai Signifikansi 0,719>0,10 mengindikasikan bahwa $\mathrm{H}_{1}$ ditolak dan $\mathrm{H}_{0}$ diterima. Hasil ini memilikiarti industri pakaian jadidengan teknologi modernmemiliki pendapatan tidak lebih tinggi daripada industri pakaian jadi dengan teknologi tradisional di Kabupaten Karangasem. Pupuh Apriadi (2015), pada penelitiannya menyatakan teknologi tidak berpengaruh signifikan terhadap pendapatan.

Berdasarkan hasil analisis pengaruh kewirausahaan terhadap pendapatan diperoleh nilai signifikansi sebesar 0,000 dengan nilai koefisien regresi 0,051 . Nilai signifikansi $0,000<0,10$ mengindikasikan bahwa $\mathrm{H}_{1}$ diterima dan $\mathrm{H}_{0}$ ditolak. Hasil ini mempunyai arti bahwa kewirausahaan berpengaruh positif dan 
signifikan terhadap Pendapatan industri pakaian jadi di Kabupaten Karangasem. Pamella (2014), menyebutkan bahwa perilaku kewirausahaan berpengaruh positif terhadap pendapatan pengusaha rajut Binong Jati. Penelitian yang dilakukan oleh Furqon (2017) juga menyatakan bahwa kewirausahaan berpengaruh positif dan signifikan terhadap pendapatan. Artinya, semakin tinggi atau semakin baik sikap kewirausahaan yang dimilikii oleh pengusaha maka semakin besar pendapatan yang diperoleh.

Berdasarkan hasil analisis pengaruh nilai produksi terhadappendapatan diperoleh nilai signifikansi sebesar 0,000 dengan nilai koefisien regresi 0,527. Nilai signifikansi $0,000<0,10$ mengindikasikan bahwa $\mathrm{H}_{1}$ diterima dan $\mathrm{H}_{0}$ ditolak. Hasil ini mempunyai arti bahwa nilai produksi berpengaruh positif dan signifikan terhadap pendapatan industri pakaian jadi di Kabupaten Karangasem.Bertambahnya produksi yang dihasilkan, maka secara otomatis akan meningkatkan penjualan perusahaan dan dengan harga yang lebih dari pengeluaran perusahaan sehingga akan mempengaruhi meningkatnya pendapatan bagi perusahaan (Arfiani, 2013), maka semakin besar nilai produksi suatu perusahaan akan berpengaruh terhadap pendapatannya.

Uji sobel atau bisa disebut juga dengan uji pengaruh tidak langsung adalah cara untuk menguji kekuatan pengaruh tidak langsung variabel eksogen (X) terhadap variabel endogen $\left(\mathrm{Y}_{2}\right)$ melalui variabel mediasi $\left(\mathrm{Y}_{1}\right)$.

Untuk mengetahui adanya pengaruh tidak langsung antara modal $\left(\mathrm{X}_{1}\right)$ terhadap pendapatan $\left(\mathrm{Y}_{2}\right)$ melalui nilai produksi $\left(\mathrm{Y}_{1}\right)$, dapat dihitung dengan uji sobel. Adapun perhitungan yang diperoleh sebagai berikut: 


$$
\begin{aligned}
S_{\beta 1 \beta 7} & =\sqrt{\beta 7^{2} S_{\beta 1}{ }^{2}+\beta 1^{2} S_{\beta 7^{2}}} \\
S_{\beta 1 \beta 7} & =\sqrt{(0,527)^{2}(0,022)^{2}+(0,985)^{2}(0,096)^{2}} \\
& =0,0953
\end{aligned}
$$

Berdasarkan perhitungan koefisien $S b_{1} b_{7}$ maka untuk menguji signifikansi pengaruh tidak langsung harus menghitung nilai z dari koefisien $S b_{1} b_{7}$ dengan rumus sebagai berikut:

$$
\begin{aligned}
Z & =\frac{\beta 1 \beta 7}{S \beta 1 \beta 7} \\
& =\frac{0,5191}{0,0953} \\
& =5,4470
\end{aligned}
$$

Oleh karena nilai z hitung sebesar 5,4470 > 1,64 hal ini berarti $\mathrm{H}_{0}$ ditolak dan $\mathrm{H}_{1}$ diterima. Dengan demikian berarti nilai produksi merupakan variabel yang memediasi pengaruh tidak langsung variabel modal terhadap pendapatan.

Untuk mengetahui adanya pengaruh tidak langsung antara teknologi $\left(\mathrm{X}_{2}\right)$ terhadap pendapatan $\left(\mathrm{Y}_{2}\right)$ melalui nilai produksi $\left(\mathrm{Y}_{1}\right)$, dapat dihitung dengan uji sobel. Adapun perhitungan yang diperoleh sebagai berikut:

$$
\begin{aligned}
S_{\beta 2 \beta 7} & =\sqrt{\beta 7^{2} S_{\beta 2^{2}}+\beta 2^{2} S_{\beta 7^{2}}} \\
S_{\beta 2 \beta 7} & =\sqrt{(0,527)^{2}(0,021)^{2}+(0,003)^{2}(0,096)^{2}} \\
& =0,0113
\end{aligned}
$$

Berdasarkan perhitungan koefisien $S b_{2} b_{7}$ maka untuk menguji signifikansi pengaruh tidak langsung harus menghitung nilai z dari koefisien $S b_{2} b_{7}$ dengan rumus sebagai berikut: 


$$
\begin{array}{r}
\mathrm{Z}=\frac{\beta 2 \beta 7}{s \beta 2 \beta 7} \\
=\frac{0,0016}{0,0113} \\
=0,1416
\end{array}
$$

Oleh karena nilai $\mathrm{z}$ hitung sebesar $0,1416<1,64$ hal ini berarti $\mathrm{H}_{0}$ diterima dan $\mathrm{H}_{1}$ ditolak. Dengan demikian berarti nilai produksi bukan merupakan variabel yang memediasi pengaruh tidak langsung variabel teknologi terhadap pendapatan.

Untuk mengetahui adanya pengaruh tidak langsung antara kewirausahaan $\left(\mathrm{X}_{3}\right)$ terhadap pendapatan $\left(\mathrm{Y}_{2}\right)$ melalui nilai produksi $\left(\mathrm{Y}_{1}\right)$, dapat dihitung dengan uji sobel. Adapun perhitungan yang diperoleh sebagai berikut:

$$
\begin{aligned}
S_{\beta 3 \beta 7} & =\sqrt{\beta 7^{2} S_{\beta 3}^{2}+\beta 3^{2} S_{\beta 7^{2}}} \\
S_{\beta 3 \beta 7} & =\sqrt{(0,527)^{2}(0,023)^{2}+(0,052)^{2}(0,096)^{2}} \\
& =0,0133
\end{aligned}
$$

Berdasarkan perhitungan koefisien $S b_{3} b_{7}$ maka untuk menguji signifikansi pengaruh tidak langsung harus menghitung nilai z dari koefisien $S b_{3} b_{7}$ dengan rumus sebagai berikut:

$$
\begin{aligned}
Z & =\frac{\beta 3 \beta 7}{s \beta 3 \beta 7} \\
& =\frac{0,0274}{0,0133} \\
& =2,0602
\end{aligned}
$$

Oleh karena nilai z hitung sebesar 2,0602 > 1,64 hal ini berarti $\mathrm{H}_{0}$ ditolak dan $\mathrm{H}_{1}$ diterima. Dengan demikian berarti nilai produksi merupakan variabel yang memediasi pengaruh tidak langsung variabel kewirausahaan terhadap pendapatan. 


\section{SIMPULAN DAN SARAN}

Modal dan kewirausahaan berpengaruh positif dan signifikan terhadap nilai produksi industri pakaian jadi di Kabupaten Karangasem. Dengan kata lain, semakin besar modal dan sikap kewirausahaan seorang pengusaha industri pakaian jadi, maka akan semakin besar pula nilai produksinya. Modal, kewirausahaan, dan nilai produksi berpengaruh positif dan signifikan terhadap pendapatan industri pakaian jadi di Kabupaten Karangasem. Dengan kata lain, semakin meningkat modal, kewirausahaan, dan nilai produksi maka dapat meningkatkan pendapatan industri pakaian jadi di Kabupaten Karangasem. Teknologi tidak memberikan pengaruh yang signifikan terhadap nilai produksi dan pendapatan industri pakaian jadi di Kabupaten Karangasem. Dengan kata lain, industri pakaian jadi dengan teknologi modern memiliki nilai produksi dan pendapatan tidak lebih tinggi daripada industri pakaian jadi dengan teknologi tradisional di Kabupaten Karangasem. Modal dan kewirausahaan berpengaruh secara tidak langsung terhadap pendapatan melalui nilai produksi, dengan kata lain nilai produksi merupakan variabel intervening yang memediasi variabel modal dan kewirausahaan terhadap pendapatan industri pakaian jadi di Kabupaten Karangasem.

Pemerintah hendaknya lebih mempermudah akses permodalan untuk setiap industri khususnya industri pakaian jadi, agar kedepannya industri pakaian jadi di Kabupaten Karangasem dapat lebih maju tanpa dihambat dengan masalah permodalan. Pengusaha industri pakaian jadi di Kabupaten Karangasem harus menumbuhkan sikap kewirausahaan agar selalu berinovasi terhadap produknya 
seiring dengan percepatan perkembangan fashion dunia yang tidak hanya mengandalkan musim tetapi tren mode, menyebabkan pesanan untuk pakaian jadi pun cepat berubah. Guna menumbuhkan sikap kewirausahaan agar selalu berinovasi, pengusaha industri pakaian jadi dapat mengikuti workshop produk pakaian jadi untuk mengetahui perkembangan permintaan pasar. Dalam meningkatkan keberhasilan usaha dan produktivitas pada industri pakaian jadi, mental kewirausahaan (entrepreneurship) menjadi hal yang penting bagi pengusaha pada industri pakaian jadi.

\section{REFERENSI}

Adhiatma, Alfian Arif. 2015. Pengaruh Modal Awal, Lama Usaha, dan Jam Kerja terhadap Pendapatan Pedagang Kayu Glondong di Kelurahan Karang Kebagusan Kabupaten Jepara. Tugas Akhir Semester, Universitas Dian Nuswantoro Semarang.

Arsha, Risma M I Made dan Ketut Suardikha Nata. 2013. Pengaruh Tingkat Upah, Tenaga Kerja Dan Modal Kerja Terhadap Produksi Industri Pakaian Jadi Tekstil (Studi Kasus Di Kota Denpasar). E-Jurnal Ekonomi Pembangunan Universitas Udayana, 2(8), hal.393-400.

Badan Pusat Statistika. 2017. Provinsi Bali Dalam Angka. 2017. Denpasar: BPS Bali.

Budiartha, I Kadek Agus dan I Gede Trunajaya. 2013. Analisis Skala Ekonomis Pada Industri Batu Bata Di Desa Tulikup, Gianyar, Bali. Jurnal Ekonomi Kuantitatif Terapan. 6(1). Hal. 55-61.

Dayuh Rimbawan, Nyoman. 2012. Pertumbuhan Ekonomi Dan Kegiatan Ekonomi Angkatan Kerja Di Provinsi Bali. Piramida, 6(2): 1918 - 1923.

Furqon, Danang Faizal. 2017. Pengaruh Modal Usaha, Lama Usaha, dan Sikap Kewirausahaan Terhadap Pendapatan Pengusaha Lanting di Lemah Duwur, Kecamatan Kuwarasan, Kabupaten Kebumen. Skripsi Jurusan Pendidikian Ekonomi pada Fakultas Ekkonomi Universitas Negeri Yogyakarta, Yogyakarta.

Hafidh, Muhammad. 2009. Pengaruh Tenaga Kerja, Modal, dan Luas Lahan Terhadap Produksi Usaha Tani Padi Sawah (Studi Kasus di Kecamatan Rowosari Kabupaten Kendal). Skripsi Sarjana Jurusan Ekonomi Pembangunan pada Fakultas Ekonomi Negeri Semarang, Semarang. 
Huazhang D. 2014. Agricultural Input and Output in Juangsu Province with Case Analysis. Journal of Agricultural Science And Technology, 15(11), pp: 2006-2010,2025.

Jena, Pradeep Kumar. 2010. Indian Handicrafts In Globalization Times: An Analysis Of Global-Local Dynamics. Journal Jawaharnal Nehru University, 8(2), pp: 119-137.

Kurniawan, Jarot. 2016. Dilema Pendidikan dan Pedapatan di Kabupaten Grobogan. Jurnal Ekonomi Kuantitatif Terapan. 9(1). Hal. 59 - 67.

Kusumastuti, Retno. 2015. Developing Innovation Capability of SME Through Contextual Ambidexterity. International Journal of Administrative Science \& Organization, 22(1), pp:51-59.

Marhaeni, AAIN et al. Evaluasi Program-program Pengentasan Kemiskinan di Provinsi Bali. Piramida, [S.1.], v. 10, n. 1, july 2014. ISSN 1907-3275.

Ningsih, Cahya I Made dan Bagus Indrajaya I Gst. 2015. Pengaruh Modal dan Tingkat Upah Terhadap Nilai Produksi Serta Penyerapan Tenaga Kerja Pada Industri Kerajinan Perak. Jurnal Ekonomi Kuantitatif Terapan, 8(1), hal. 83 -91 .

Nugraha, Kunta dan Phil Lewis. 2013. Towards a Better Measure of Income Inequality in Indonesia. Bulletin of Indonesian Economic Studies. 49(1). Pp. $103-112$.

Ovtchinnikov, Alexei V. 2010. Capital Structure Decisions: Evidence from Deregulated Industries. Journal of Financial Economics, 95(2), pp: 249274.

Pamella, Komang Elfa. 2014. Pengaruh Perilaku Kewirausahaan Terhadap Pendapatan Pengusaha Rajut di Sentra Industri Rajut Binong Jati Kota Bandung. Skripsi Sarjana Jurusan Pendidikan Ekonomi pada Fakultas Ekonomi dan Bisnis Universitas Pendidikan Indonesia, Bandung.

Prastyo, Didik; Kartika, I Nengah. Analisis Faktor-Faktor Yang Mempengaruhi Produksi Ayam Broiler di Kecamatan Marga, Kabupaten Tabanan. Piramida, [S.1.], v. 13, n. 2, p. 77-86, dec. 2017. ISSN 1907-3275.

Pratama, Arma B. 2010. Analisis Faktor - Faktor Yang Mempengaruhi Kebijakan Penyaluran Kredit Perbankan (Studi Pada Bank Umum Di Indonesia Periode Tahun 2005 - 2009). TesisJurusan Magister Manajemen pada Fakultas Ekonomika dan Bisnis Universitas Diponegoro, Semarang.

Pratiwi, Ayu Manik; Bendesa, I K G; Yuliarmi, Nyoman. Analisis Efisiensi dan Produktivitas Industri Besar dan Sedang di Wilayah Provinsi Bali (Pendekatan Stochastic Frontier Analysis). Jurnal Ekonomi Kuantitatif Terapan, [S.1.], february 2014. ISSN 2301-8968 
Prianata, Rahardian dan Suardhika Nata, Ketut. 2014. Pengaruh Jumlah Tenaga Kerja, Bahan Baku, dan Teknologi Terhadap Produksi Industri Furniture di Kota Denpasar. E-jurnal Ekonomi Pembangunan Universitas Udayana. 3(1). Hal. 11-18.

Priyandika, Akhbar Nurseta. 2015. Analisis Pengaruh Jarak, Lama Usaha, Modal, Dan Jam Kerja Tehadap Pendapatan Pedagang Kaki Lima Konveksi (Studi Kasus Di Kelurahan Purwodinatan Kota Semarang). Skripsi Sarjana Jurusan Ilmu Ekonomi Studi Pembangunan pada Fakultas Ekonomika dan Bisnis Universitas Diponegoro, Semarang.

Putri, Ni Made Dwi Maharani dan Jember, I Made.2016. Pengaruh Modal Sendiri dan Lokasi Usaha Terhadap Pendapatan Usaha Mikro Kecil Menengah (UMKM) di Kabupaten Tabanan (Modal Pinjaman sebagai Variabel Intervening). Jurnal Ekonomi Kuantitatif Terapan, 9(2), hal.142-150.

Rahman, Abdul dan Awalia, Nuratul. 2016. Faktor Yang Mempengaruhi Pendapatan Nelayan di Desa Aeng Batu-Batu Kecamatan Galesong Utara Kabupaten Takalar. EcceS (Economics, Social, and Development Studies). 3(1), 16-34.

Seoki, Lee. 2010. Effects Of Capital Intensity On Firm Performance: The U.S. Restaurant Industri. The Journal of Hospitality Financial Management, 18(1), pp: 1-13.

Setyawan, I Gusti Ngurah Adi, Sukadana, I Wayan dan Detriasmita Saientisna, Made. 2017. Peran E-commerce Terhadap Penjualan Usaha pada Industri Pakaian jadi di Provinsi Bali. E-Jurnal Ekonomi Pembangunan Universitas Udayana, 6(12), hal. 2436-2461.

Shanmugasundaram, S dan N. Panchanatham. 2011. Embracing Manpower for Produktivity in Apparel Industry. International Journal of Innovation, Management and Technology. 2(3). Pp. 232 - 237.

Sukmanegara, Prima. 2011. Analisis Pengaruh Indeks Pembangunan Manusia, PDRB Per Kapita dan Jumlah Pengangguran Terhadap Jumlah Penduduk Miskin di Jawa Tengah. Skripsi Sarjana Jurusan Ilmu Ekonomi Studi Pembangunan pada Fakultas Ekonomi Universitas Diponegoro, Semarang.

Utari, Tri dan Martini Dewi Putu. 2014. Pengaruh Modal, Tingkat Pendidikan Dan Teknologi Terhadap Pendapatan Usaha Mikro Kecil Dan Menengah (UMKM) Di Kawasan Imam Bonjol Denpasar Barat. E-Jurnal Ekonomi Pembangunan Universitas Udayana, 3(12), hal.576-585.

Vargas - Hernandez Jose G. 2015. Growth and Development Analysis of Group Mexico in the Mining Industri. International Journal of Ekonomics and Management Science, 4(6), pp: 1 - 6. 
I Wayan Wira Putra dan I Made Jember. Pengaruh Modal, Teknologi dan Kewirausahaan............

Widodo, Wahyu. 2014. Ekonomi Aglomerasi, Firm-level Efisiensi, dan Produktivitas Pertumbuhan (Bukti empiris dari Indonesia). Bulletin Of Indonesian Economic Studies (BIES). 50(2). Pp: 291-292.

Zulhanafi, Hasdi Aimon dan Efrizal Syofyan. 2013. Analisis Faktor - Faktor Yang Mempengaruhi Produktivitas dan Tingkat Pengangguran di Indonesia. Jurnal Kajian Ekonomi, 2(3), hal. 85 - 109. 